\title{
Score Table Volleyball Computer-based
}

\author{
Sri Ayu Wahyuti ${ }^{1}{ }^{*}$ Siswantoyo Siswantoyo ${ }^{1}$, Suhadi Suhadi ${ }^{1}$, Resti Utami ${ }^{1}$ \\ ${ }^{1}$ Faculty of Sport Sciences, Universitas Negeri Yogyakarta, Yogyakarta, Indonesia \\ "Corresponding author.Email: sri0001pasca.2020@student.uny.ac.id
}

\begin{abstract}
This study aims to produce a product in the form of a computer-based volleyball score table application that is packaged into a compact disk (CD) along with an effective and efficient guidebook in competitions. This study uses the Research and Development (R\&D) method. Expert validation by material experts and media expert validation using a questionnaire instrument. The product trial consists of two stages, namely small group trials and large group trials. The number of subjects for the small group trial was 7 people; the large group trial was 31 people. The results showed that the quality of the product as a result of the material expert's validation was "Very good" with an average of 4.55 , and the results of the media expert's validation included "Very Good" with an average of 4.6. The quality of the product from the small group trial had "Very good", with a mean score of 4.23. Subsequently, a large group trial was conducted with the quality of the athletes and coaches' assessment products in the "Very good" category with an average of 4.43. The product quality results are based on the referee's assessment of the "Very Good" type with an average score of 4.25. Based on the study results, it can be concluded that the computer-based volleyball score table media is declared feasible and efficient to use in volleyball match activities and match simulations during practice.
\end{abstract}

Keywords: Development, score table, volleyball

\section{INTRODUCTION}

Volleyball is a sport that the wider community and the world have recognized. Volleyball is a popular sport that is often played by everyone [1]. This is proven by including volleyball in every national, intercountry and international event, such as PON, Asian Games, and Sea Games. Volleyball is a sport with technical characteristics, and accuracy is the most important aspect to achieve victory [2].

The progress of science is currently very fast along with the progress of the times. We have entered the era of technology and industry 4.0 challenges. Some sciences must quickly adapt to these needs, one of which is sports. The field of sports is one of the branches of education; the emergence of innovative products marks this progress in training methods, structures, and infrastructure used to improve skills in sports [3]. The rapid development of technology today has brought us to modernization and the digital era. Almost every aspect of human life is highly dependent on technology because it was developed to make it easier for humans to carry out an activity/work [4]. Technological developments in sports are proven by many changes ranging from infrastructure, information, match systems to referees [5].

Current technological developments have penetrated all aspects of life. Now it seems as if people have been spoiled by tools that can provide convenience in daily activities. One of them is a computer [6]. Computers at this Time became a necessity that everyone must own for various things such as communication, social networking, and entertainment as a medium for obtaining and processing information data [7]. In line with the development of sophisticated technology, many software development programs can be used. For example, Visual Basic 6.0, Matlab, App inventor, and many more. Each program has its advantages and disadvantages, both in terms of performance or ease of use by users. The Visual Basic program was chosen because it can run on computers with low specifications and uses a language easily learned. However, the Visual Basic program is classified as a lightweight application also has many exclusive features.

In the world of sports, the scoreboard has an important function as a tool to announce and record the results of a match so that spectators and athletes can find out the results of the score of the match [8]. There are many ways to get a game score, starting with writing on a piece of cardboard or a plywood board, announcing it on a speaker or microphone and the like. In the world of sports, the scoreboard plays a very important role. This scoreboard is a tool widely used in sports to facilitate registration and as a tool to 
announce the results of sports matches to the public. This scoreboard is also very important for athletes in a game; with this scoreboard, athletes can see temporary scores and calculate which strategies can be used to win the game [9].

The use of manual table scores at this Time still has many shortcomings. Its use requires active control of the second referee and scorer. Often the assistant scorer neglects to control the score of the match. Negligence was made when controlling the match score, and the scorer was often negligent in operating the score and technical timeout/timeout. When the match has reached a score of 8 and 16, a technical timeout must be made, and the second referee presses the Time for 60 seconds. Technical timeout is allowed to rest for the two teams that are already in the PBVSI (Indonesian Volleyball Association) match rules when the score is 8 and 16. Timeout is a request for rest from each coach to take a break or evaluate. However, the timeout that has been expected so far is not by the Time of the PBVSI (Indonesian Volleyball Association) match rules with a timeout of 30 seconds.

Based on interviews with trainers conducted at several training sites in Sleman, Yogyakarta Municipality, and Wonosobo, Central Java. At the Time of technical timeout and timeout in a volleyball match, the coach only focuses on evaluation so that the coach does not care about how long the actual Time is. This shows that the coach's lack of accuracy in technical timeouts and timeouts. It can be concluded that the need for effective and efficient scoring. It is hoped that the media will help reduce the obstacles that occur during the match process.

To overcome these problems, by following the current developments in science and technology, it is necessary to develop innovations to improve the scoring system in volleyball. The researcher chose to create a computer-based table score. The development of this scoring table develops the score table that already exists in the previous international matches. This development is expected to be implemented to overcome the improvement of scoring in the implementation of volleyball matches. The volleyball score table application will provide warning sensors when the match scores are 8 and 16, and there is a technical timeout until the end of the technical timeout and the end of the timeout.

\section{METHODS}

\subsection{Participants}

The trial subjects in this development research were licensed referees, athletes and trainers in the Sleman area, Bantul Yogyakarta. The trial was carried out through several stages. The first stage is a group trial with 7 research subjects, and the second stage is a large group trial with a total of 31 research subjects.

\subsection{Procedure}

This research is a research development or Research and Development (R\&D). Development research methods are used to produce certain products and test the effectiveness of these products [10]. The procedure used in this development research adopts the Sugiyono model.

\subsection{Data Collection}

This study collects data using qualitative data techniques and quantitative data analysis. The data from the content analysis is qualitatively obtained through expert validation activities and trial activities in the form of input, feedback, and criticism and suggestions, analyzed by descriptive quantitative analysis. The questionnaire used in this study is an assessment or response questionnaire in the form of answers "VERY LESS", "LESS", "ENOUGH", "GOOD", and "VERY GOOD". Based on the number of opinions or answers, the researcher then averaged each answer using the Eko Putro Widyoko formula [11]

\section{RESULTS}

\section{1. media and material}

Researchers developing computer-based volleyball score table media assist the referee in leading the match. Referees and volleyball application operators must understand the application material to use the media. Experts validated the development of this volleyball score table in their fields, namely a material expert and media expert, as follows:

Table 1. Results of media and material expert validation

\begin{tabular}{|l|l|l|}
\hline No & Expert & Average \\
\hline 1 & Material & $\mathbf{4 , 5 5}$ \\
\hline 2 & Media & $\mathbf{4 , 6}$ \\
\hline Criteria & Very Good \\
\hline
\end{tabular}

\subsection{Small-Scale Product Trial}

Data were taken with the number of subjects 7 people. Data were obtained from a questionnaire, then analyzed. The data obtained from the small group trial consisted of three assessment aspects, namely the display aspect consisting of 9 items, material aspects, 4 items and programming aspects, 5 items. The study results regarding the assessment aspect of the small group trial media showed that the mean score of 4.23 was categorized as "very good". 
Tabel 2. Small-Scale Product Trial

\begin{tabular}{|c|c|c|}
\hline No & Assessment Aspect & Average \\
\hline 1 & Appearance & 4,1 \\
\hline 2 & Material & 4,35 \\
\hline 3 & Programming & 4,22 \\
\hline \multicolumn{2}{|c|}{ Average } & 4,23 \\
\hline & Criteria & Very Good \\
\hline
\end{tabular}

\subsection{Large-scale product trial}

Based on the results of a large group trial with 22 athletes, 2 coaches, and 5 referees from Pervas volleyball club and Baja 78 volleyball club, volleyball clubs. The assessment from coaches and athletes consists of the appearance aspect. Meanwhile, the three aspects of the referee's assessment are the display aspect, the material aspect, and the programming aspect. It can be concluded that the media score table volleyball assessment from athletes and coaches includes the criteria of "Very Good" with a score of 4.43. In contrast, the assessment of the referee's criteria is "Very Good with an average of 4.25.

Tabel 3. Assessment of athletes and coaches

\begin{tabular}{|c|c|c|}
\hline No & Assessment Aspect & Average \\
\hline 1 & Appearance & 4,43 \\
\hline \multicolumn{2}{|c|}{ Criteria } & Very Good \\
\hline
\end{tabular}

Tabel 4. Review Assessment

\begin{tabular}{|c|c|c|}
\hline No & Assessment Aspect & Average \\
\hline 1 & Appearance & 4,22 \\
\hline 2 & Material & 4,3 \\
\hline 3 & Programming & 4,24 \\
\hline \multicolumn{2}{|c|}{ Average } & 4,25 \\
\hline \multicolumn{2}{c}{ Criteria } & Very Good \\
\hline
\end{tabular}

\section{DISCUSION}

Products developed using Visual Basic 0.6 and Crystal Report. This product contains volleyball match scoresheets and outputs according to the official volleyball regulations for 2015-2016. According to Atmoko [12], "Crystal Report is a component that we will use to create reports or reports from the program that we will create, so that it can be understood by users, whose reports are taken from a collection of data from tables stored in the SQL Server database."

According to Wahyu [13], Crystal Reports is designed to create reports that can be used with various Windows-based programming languages, such as Visual Basic, Visual $\mathrm{C} / \mathrm{C}++$, Visual Interdev, and Borland Delphi. Now, the Crystal Report program is integrated into Visual Basic 306.0 to become part of the IDE (integrated development environment) development environment for Visual Basic 6.0 applications. This is especially evident in the crystal report designer section for designing and modifying reports. To make it easier to make reports, a Crystal Report Experts feature is provided, similar to the wizard in Microsoft.

Meanwhile, according to MADCOMS [14], "Crystal Report is a separate program from the Microsoft Visual Basic 6.0 program, but both can be linked (linkage)". Understood by the user, based on the data stored on the SQL server.

The product above the researcher designed the Time between sets to start the next game. The official rules of volleyball or PBVSI state that the time-lapse is the Time between sets; several things must be known in the interval time; namely, the entire interval is 3 minutes, between the second and third sets is 10 minutes, at the end of each set the two players swap field except in the determinant [15].

At the beginning of the development of the volleyball score table, it was designed and produced into a computer-based volleyball score table packaged in a CD (compact disk) and a manual. Several examples in the computer-based volleyball score table media picture described above are based on the 20152016 All-Indonesia Volleyball Regulations (PBVSI) and several experts. Media advantages; (1) Loads the output for volleyball match results automatically, while the previous output uses the match results report manually, (2) the researcher automatically designed the media for the technical timeout and timeout alarms, while the previous technical timeout and timeout alarms used a buzzer, so it took Time to press, (3) the researcher designed the product to display all players and officials so that they did not rewrite the output for the results of volleyball matches, (4) researchers show the rotation of players and core players, while the previous scoring has never shown rotation, and (5) the media displays Indonesian Time.

This media can be a solution to help referees calculate, recap match results, and make it easier for spectators and coaches to see the score calculation directly and transparently, as well as make blocking sports more efficient so that the score sheet tool can be helpful and can be owned by all.

\section{CONCLUSION}

The research conducted by the researcher was able to develop volleyball scoring in the form of a computer-based volleyball score table application that aims to produce a computer-based volleyball score table application that is packaged into a compact disk (CD) along with a manual. A computer-based volleyball score table was developed using a research 
and development (R \& D) approach. The overall score table volleyball application is feasible for use in volleyball matches after going through several stages of expert validation and 2 trial stages. The validation level of material experts with an average of 4.55 is categorized as "very good" and media experts with an average of 4.6 "very good". A small group trial of 7 referees with an average of 4.23 "very good" and a large group of 5 referees with an average of 4.43 "very good", 26 coaches or athletes with an average of 4.25 were categorized as "very good". The development of this computer-based volleyball score table has been achieved for use in a volleyball sport event.

\section{REFERENCES}

[1] Closs B, Burkett C, Trojan JD, Brown SM, Mary K, Closs B, et al. Recovery after volleyball : a narrative review. Phys Sportsmed [Internet]. (2019) ;0(0):1-9. Available from: https://doi.org/10.1080/00913847.2019.1632156

[2] D'Isanto, T., Allavilla, G., \& Dkk. Teaching method in volleyball service: Intensive and exenstive tools in cognitive and ecological approach. Journal of Physical Education and Sport, (2017), 17(5)

[3] Supriyono, E. Pengembangan aplikasi tes keterampilan sepakbola berbasis web. Jurnal Keolahragaan, 6(1), 38-47 (2018), https://doi.org/10.21831/jk.v6i1.12764

[4] Eddi, Suhery, C., \& Triyanto, D. Sistem Penerangan Rumah Otomatis Dengan Sensor Cahaya Berbasis Mikrokontroler. Tugas Akhir, (2013), 01(2), 1-10.

[5] Chin, E., Felt, A. P., \& Wagner, D. Analyzing InterApplication Communication in Android. 2011.
[6] Kaderi, C. Rancang bangun aplikasi data nasabah pada koperasi berkat cabang kota palopo. Universitas Cokroaminoro Palopo, 2017.

[7] Nurzahidah, Perancangan system informasi pengolahan data pegawai berbasisclient server pada kantor dinas perhubungan kota palopo. Universitas Cokroaminoro Palopo, 2017.

[8] Liliana, Maria S.P, Suprianto. Rancang Bangun Papan Skor Olahragaberbasis mikrokontroler ATMEGA 8535 dengan inputan keyboard komputer, (2013) http://ejournal.uin-suska.ac.id/index.php/sitekin/ article/view/565)

[9] Hasanah, Nur., Rachmansyah \& Widiyanto, E. P. Rancang Bangun Pencatat Scoreberbasis Mikrokontroler Dengan Pengiriman Data Menggunakan Wireless. 2012.

[10] Sugiyono. Metode penelitian kuantitatif, kualitatif, dan R\&D. Bandung: PT Alfabeta, 2009.

[11] Widyoko, E.P. Evaluasi program pembelajaran. Yogyakarta: Pustaka Pelajar, 2009.

[12] Atmoko, E.H. Program Akuntansi beserta Manajemen Aset Menggunakan VB dan SQL Server. Jakarta: PT: Elex Media Komputindo. 2013

[13] Wahyu, A. O., Edi, Noersasongko. Sistem Pendukung Keputusan Kelayakan Pemberian Kredit Motor Menggunakan Metode Simple Additive Weighting Pada Perusahaan Leasing HD Finance. Semarang: (2014). Jurnal SPK Kelayakan Pemberian Kredit Motor.

[14] MADCOMS. Seri panduan pemograman microsoft visual basic 6.0. Yogyakarta: ANDI Gas, 2002.

[15] D'Isanto, T., Allavilla, G., \& Dkk.. Teaching method in volleyball service: Intensive and exenstive tools in cognitive and ecological approach. Journal of Physical Education and Sport, (2017) 17(5) 